\title{
Biaya Keagenan, GCG, dan Kinerja Perusahaan Keluarga
}

\author{
Kusmawati \\ Unika Musi Charitas \\ Email: atkusma@gmail.com
}

\begin{abstract}
This research according to agency theory, especially conflict between principal and agent in family firm. The purpose of this study was to examine empiricallly differences agency cost, GCG, and performance in family firm and not family firm. proxy chosen in describing the agency cost are operational expense ratio on revenue, performance of the firm is return on asset, and top 50 biggest market cap and mid cap of public listed companies in IICD for the GCG measurement. The population used in this study is company in 100 kompas index, during the period 2017-2019. The sample collected by saturation method and secondary data obtained from a IDX.co.id database. In this study, the data collected were 28 family firm and 43 non family firm. The statistically method are used Mann Whitney U and Chi Square with using IBM SPSS 23.0 for data processing. The first result of this research showed that there are differences in agency cost and Good Corporate Governance among family with non family firm. The second result are showed that there are not difference in Return On Asset among family with non family firm.
\end{abstract}

Keywords: Agency Cost, GCG, ROA

\begin{abstract}
Abstrak
Penelitian ini adalah penelitian tentang teori keagenan, khususnya konflik antara pemilik dan agen di perusahaan keluarga. Tujuan dari penelitian ini adalah untuk menguji secara empiris perbedaan antara biaya keagenan, GCG, dan kinerja antara perusahaan keluarga dan bukan perusahaan keluarga. Proksi yang dipilih untuk menggambarkan biaya keagenan adalah rasio beban operasi atas pendapatan, ukuran kinerja adalah laba bersih atas aset, dan perusahaan yang masuk dalam 50 perusahaan dengan market kapitatalisasi besar dan menengah untuk ukuran dari GCG. Populasi yang digunakan dalam penelitian ini adalah perusahaan yang masuk dalam index kompas 100 selama periode 2017-2019. Sampel dipilih dengan menggunakan metode sampel jenuh dan data sekunder yang digunakan adalah berasal dari database idx.co.id. dalam penelitian ini, data yang dikumpulkan terdiri dari 28 perusahaan keluarga dan 43 perusahaan non keluarga. Metode statistik yang digunakan adalah Mann Whitney U dan Chi Square dengan menggunakan SPSS IBM versi 23 untuk pengolahan datanya. Hasil penelitian menunjukkan bahwa terdapat perbedaan biaya keagenan dan GCG antara perusahaan keluarga dan perusahaan non keluarga. Hasil penelitian berikutnya menunjukkan bahwa tidak terdapat perbedaan kinerja ROA antara perusahaan keluarga dan non keluarga.
\end{abstract}

Kata Kunci: Biaya Keagenan, GCG, ROA.

\section{Pendahuluan}

Suatu perusahaan dikelola oleh keluarga bukanlah suatu yang asing di Indonesia. Mulai dari perusahaan yang tidak go public sampai dengan perusahaan yang sudah dipublikasikan di bursa efek. Hasil survey perusahaan audit Price Waterhouse Cooper $(\mathrm{PwC})$ tentang bisnis keluarga di Indonesia tahun 2014, menunjukkan bahwa lebih dari 95 persen perusahaan di Indonesia merupakan bisnis keluarga (www.cnnindonesia.com, 2020). Masih di tahun yang sama, penelitian Muawanah (2014) mengatakan bahwa 66,70\% kepemilikan BPRS berada pada individu-individu (keluarga) pendiri dan menempati posisi sebagai pemegang saham pengendali. 
Perusahaan yang didirikan dan dikelola oleh keluarga memiliki hal positif dan negatif. Keluarga yang menjadi pendiri dan sekaligus pengelola perusahaan akan selalu berusaha mempertahankan keberlangsungan hidup perusahaan karena ini terkait dengan nama baik keluarga. Menurut The Jakarta Consulting Group (2019), sebuah perusahaan keluarga kemungkinan tidak tertarik untuk memperoleh keuntungan finansial jangka pendek yang dapat menodai kedudukan keluarga dalam perusahaan. Orientasi laba jangka panjang menuntut perusahaan untuk melakukan inovasi produk yang membuat produk perusahaan akan selalu digunakan oleh konsumen, sebagaimana yang disampaikan oleh Sun Life Financial Inc dari hasil survey tentang bisnis keluarga di Indonesia (https://youngster.id, 2020).

Hal positif lainnya adalah bahwa dalam perusahaan keluarga manajer menempatkan diri menjadi prinsipal sekaligus menjadi agen. Kondisi ini dapat menghilangkan konflik keagenan antara agen dan principal dampaknya upaya melakukan pengawasan terhadap tindakan agen akan semakin berkurang sehingga biaya keagenanpun akan berkurang. Hal ini sebagaimana yang dikatakan oleh Muawanah (2014) tentang pemisahan kepemilikan dan pengendalian di Bank Perkreditan Rakyat Syariah (BPRS) yang ditetapkan oleh Bank Indonesia. Dia mengatakan bahwa pemisahan dan pengendalian pada BPRS bersifat semu, sehingga pedoman pelaksanaan corporate governance yang bersifat mandatory bagi perbankan syariah yang ditetapkan oleh Bank Indonesia berpotensi untuk tidak efektif diterapkan.

Sisi negatif dari perusahaan keluarga adalah segala sesuatu tergantung dari atasan (the moon culture) sehingga karyawan menjadi kesulitan dalam bersikap, sebagaimana yang dikatakan oleh The Jakarta Consulting Group (2019). Kondisi ini juga dapat menimbulkan konflik antara karyawan yang bukan keluarga dan karyawan yang berasal dari keluarga pemilik perusahaan. Menurut Kusuma (2018), masalah nepotisme juga menjadi sisi negatif dari perusahaan keluarga yaitu dalam hal penunjukan seseorang untuk menjabat sebagai manajer. Ketidakyakinan akan kemampuan seseorang yang menduduki jabatan karena faktor kekerabatan dapat menimbulkan konflik keagenan dan berarti juga menimbulkan biaya keagenan.

Keluarga dalam manajemen perusahaan bisa saja mengambil keputusan hanya untuk menguntungkan pihaknya dengan melakukan ekspropriasi. Ekspropriasi merupakan tindakan yang dilakukan pemegang saham pengendali untuk memaksimumkan kesejahteraan sendiri dengan menggunakan hak kendali yang dimiliki (Claessens et al, 2000). Ekspropriasi tersebut dapat berupa pemberian gaji dan bonus yang berlebihan ataupun melakukan transaksi dengan pihak yang berelasi.

Adanya dampak positif dan negatif dari kepemilikan keluarga dalam perusahaan menimbulkan permasalahan tentang penerapan good corporate governance (GCG), biaya keagenan, dan kinerja pada perusahaan keluarga. Apakah ketiga hal ini diterapkan secara sama antara perusahaan keluarga dan bukan perusahaan keluarga.

\section{Kajian Pustaka}

\subsection{Teori Keagenan}

Teori keagenan atau yang sering disebut dengan agency theory merupakan salah satu teori mengenai dampak serta hubungan antara agent dengan principal atau principal dengan principal Meckling (1976). Principal yang dimaksud adalah pemegang saham dan pemilik perusahaan. Sementara agent adalah pihak ketiga yang ditunjuk principal untuk melaksanakan tugasnya di perusahaan mereka. Menurut Jensen dan Meckling (1976): 
"a contract under which one or more persons (the principal/s) engage another person (the agent) to perform some service on their behalf which involve delegating some decisions making authority to the agent. If both partners to the relationship are utility maximizers there us good reason to believe that the agent will not always act in the best interest of the principal."

Hubungan antara agen dan prinsipal menurut Jensen dan Meckling (1976) merupakan sebuah hubungan kontrak yang dilakukan antara satu orang atau lebih terhadap pihak lain (agent) yang melakukan beberapa pekerjaan atas nama mereka (principal) yang melibatkan pendelegasian pengambilan keputusan kepada agent. Tanggung jawab para agen adalah untuk mengelola dan mengembangkan perusahaan yang sudah dipercayakan kepada mereka dari para principal berdasarkan prinsip akuntabel dan transparansi. Tanggung jawab para principal adalah mengawasi kinerja agen mereka dalam mengelola perusahaan, juga menjamin kesejahteraan agen agar kinerja agen baik dan loyal terhadap perusahaan. Principal juga harus mempertanggungjawabkan apa yang terjadi di perusahaan kepada para pemangku kepentingan lain.

Dalam hal kemampuan memperoleh informasi, posisi agen dan prinsipal adalah asymetric information, sebagaimana yang dikatakan oleh Litz et al. (2004). Agen memiliki informasi yang lebih banyak dibanding prinsipal, karena agen berada dalam perusahaan sementara principal di luar perusahaan. Kondisi sebaliknya terjadi di perusahaan keluarga yaitu prinsipal memiliki kesetaraan informasi seperti agen. Prinsipal yang juga berposisi sebagai agen membuat informasi yang dimiliki prinsipal dapat setara dengan agen.

\subsection{Biaya keagenan}

Berdasarkan teori keagenan Jensen dan Meckling (1976), diketahui bahwa prinsipal dan agen adalah pihak yang berbeda kepentingan. Pihak prinsipal berkepentingan tentang kepastian tingkat pengembalian atas modal yang ditanamkan. Pihak agen berkepentingan atas kepastian kompensasi yang akan diterima.

Adanya asymetric information antara agen dan prinsipal, menempatkan agen memiliki informasi lebih banyak dibanding principal dan dapat menimbulkan kesempatan bagi agen untuk mengambil keputusan yang menguntungkan agen. Hal ini sebagaimana yang dikatakan oleh Litz et al (2014). Perbedaan kepentingan dan adanya moral hazard ini dapat menimbulkan konflik keagenan, yang akan memicu munculnya biaya keagenan.

Menurut Jensen Meclng (1976) biaya keagenan adalah penjumlahan antara monitoring cost, bonding cost, dan residual losses. Monitoring cost adalah biaya pengawasan perilaku agen yang dikeluarkan oleh principal. Bonding cost adalah biaya yang dikeluarkan oleh agen untuk pemenuhan kepentingan principal, seperti biaya penyusunan laporan keuangan. Residul losses adalah biaya yang dikeluarkan oleh principal karea agen tidak melakukan kebijakan yang sesuai dengan kebutuhan manajer.

Penentuan biaya keagenan menurut Michael J dan William M (1976) mirip dengan pendapat Jensen Mecling (1976), yaitu :

a. Biaya yang dikeluarkan untuk mengawasi aktivitas manajerial, contohnya biaya audit.

b. Biaya yang dikeluarkan untuk membatasi tindakan manajemen yang tidak diinginkan. Contohnya menunjuk anggota dari luar untuk dewan direksi atau hierarki manajemen.

c. Biaya peluang (opportunity cost) ketika suara pemegang saham dibatasi. 
Ang et al (2000) menunjukkan ukuran yang berbeda dari biaya keagenan, yaitu dilihat dari dua rasio yaitu expense ratio menurut literatur akuntansi dan rasio utilisasi aset menurut literatur keuangan. Expense ratio diukur menggunakan rasio beban operasi atas penjualan. Rasio Beban operasi dapat menggambarkan beban diskresi manajer dalam membelanjakan sumberdaya nya untuk kepentingan principal. Utilisasi aset diukur dengan asset turnover ratio, untuk melihat efisiensi penggunaan aset. Dengan semakin tinggi asset turnover ratio, maka semakin produktif aset digunakan untuk kepentingan prinsipal.

\subsection{Good Corporate Governance}

Menurut idx.co.id, 24 Desember 2020, Tata Kelola Perusahaan merupakan suatu sistem yang dirancang untuk mengarahkan pengelolaan perusahaan secara profesional berdasarkan prinsipprinsip transparansi, akuntabilitas, tanggung jawab, independen, kewajaran dan kesetaraan. Menurut Riadi (2016) Corporate governance merupakan salah satu konsep yang dapat dipergunakan dalam meningkatkan efisiensi ekonomis, yang meliputi serangkaian hubungan antara manajemen perusahaan, dewan direksi, para pemegang saham dan pemangku kepentingan perusahaan lainnya. Corporate governance juga memberikan suatu struktur yang memfasilitasi penentuan sasaran-sasaran dari suatu perusahaan, dan sebagai sarana untuk menentukan teknik monitoring kinerja.

Definisi tata kelola lebih jelas ditunjukkan oleh Forum for Corporate Governance in Indonesia atau FCGI (2000) dalam publikasi pertamanya. Dengan mempergunakan definisi Cadbury Committee, tata kelola yaitu seperangkat peraturan yang mengatur hubungan antara pemegang saham, pengurus (pengelola) perusahaan, pihak kreditur, pemerintah, karyawan serta para pemegang kepentingan intern dan ekstern lainnya yang berkaitan dengan hak-hak dan kewajiban mereka, atau dengan kata lain suatu sistem yang mengatur dan mengendalikan perusahaan. Disamping itu FCGI juga menjelaskan, bahwa tujuan dari Corporate Governance adalah untuk menciptakan nilai tambah bagi semua pihak yang berkepentingan (stakeholders).

Definisi tata kelola menurut Wikipedia, idx.co.id, FCGI dan menurut Riadi (2016) menunjukkan bahwa tata kelola adalah sistem pengawasan terhadap manajemen perusahaan berdasarkan prinsip-prinsip tata kelola yang dapat meningkatkan efisiensi untuk memenuhi kepentingan para pemangku kepentingan. Pemangku kepentingan menurut Wikipedia adalah pemegang saham, karyawan, pelanggan, bank dan kreditor, regulator lingkungan serta masyarakat luas.

Definisi tata kelola juga menggambarkan tentang penjaminan penerapan prinsip keagenan yaitu tanggung jawab para agen untuk mengelola dan mengembangkan perusahaan yang sudah dipercayakan kepada mereka dari para principal berdasarkan prinsip akuntabel dan transparansi. Begitu juga sebaliknya, principal bertanggungjawab dalam mengawasi kinerja agen dalam mengelola perusahaan, juga menjamin kesejahteraan agen agar kinerja agen baik dan loyal terhadap perusahaan. Selain itu, principal juga harus mempertanggungjawabkan apa yang terjadi di perusahaan kepada para pemangku kepentingan lain.

Menurut FCGI (2001:4), keberadaan corporate governance dalam perusahaan memberikan manfaat, yaitu antara lain:

1. Meningkatkan kinerja perusahaan melalui terciptanya proses pengambilan keputusan yang lebih baik, meningkatkan efisiensi operasional perusahaan serta lebih meningkatkan pelayanan kepada stakeholders.

2. Mempermudah diperolehnya dana pembiayaan yang lebih murah dan tidak rigid (karena faktor kepercayaan) yang pada akhirnya akan meningkatkan corporate value. 
3. Mengembalikan kepercayaan investor untuk menanamkan modalnya di Indonesia.

4. Pemegang saham akan merasa puas dengan kinerja perusahaan karena sekaligus akan meningkatkan shareholder's value dan dividen. Khusus bagi BUMN akan dapat membantu penerimaan bagi APBN terutama dari hasil privatisasi.

GCG saat ini sudah dilakukan pemeringkatan untuk menilai perusahaan yang dapat dipercaya. Salah satu lembaga pemeringkatan adalah IICD (Institute for Corporate Directorship) yang sudah melaksanakan kegiatannya sejak tahun 2005 dengan metode CG scorecard OECD yang merupakan standar internasional. IICD didirikan tahun 2000, IICD merupakan organisasi nirlaba yang bertujuan melaksanakan internalisasi dan mendukung penerapan praktik GCG di Indonesia. Penilaian untuk pemeringkatan meliputi hak-hak pemegang saham, perlakuan yang setara terhadap pemegang saham, peran pemangku kepentingan, pengungkapan dan transparansi, serta tanggung jawab dewan.

IICD melakukan penilaian terhadap 200 emiten dengan market kapitalisasi terbesar yang terdaftar di BEI, dimana emiten-emiten tersebut dibagi menjadi 2 kelompok, yaitu 100 emiten dengan market kapitalisasi terbesar (big cap) dan 100 emiten dengan market kapitalisasi menengah (mid cap), yang didukung oleh 10 asesor dan 4 reviewer.

\subsection{Perusahaan Keluarga}

Definisi perusahaan keluarga memiliki beberapa definisi. Adapun definisi tersebut antara lain:

1. Menurut John L. Ward dan Craig E. Aronoff (2002), suatu perusahaan yang dalam struktur kepemilikan terdapat dua atau lebih anggota keluarga yang mengawasi keuangan perusahaan maka perusahaan tersebut dikatakan sebagai perusahaan keluarga.

2. Menurut Robert G. Donnelley (2002), suatu organisasi dinamakan perusahaan keluarga apabila paling sedikit ada keterlibatan dua generasi dalam keluarga tersebut dan mereka mempengaruhi kebijakan perusahaan.

3. Menurut Villalonga dan Amit (2006) sebagian besar definisi tentang perusahaan keluarga setidaknya mencakup tiga dimensi, yaitu: satu atau beberapa keluarga memegang bagian penting dari modal perusahaan; anggota keluarga mempertahankan kendali yang besar pada perusahaan (misalnya, distribusi modal dan hak suara) dengan kemungkinan pembatasan undang-undang atau hukum; dan anggota keluarga berada pada posisi manajemen puncak.

4. Menurut Susanto et al,. (2007:23). Di Indonesia perusahaan keluarga pada awalnya didirikan oleh single fighter dan selanjutnya melibatkan mitra yang masih termasuk dalam close-circle family atau immediate family, seperti suami/istri, saudara, hingga teman dekat

5. Menurut Andres (2008), perusahaan keluarga dikelompokkan dalam dua kriteria yaitu a) pendiri atau anggota keluarga memiliki saham sebesar 25\% atau lebih; dan b) terdapat anggota keluarga yang menduduki kursi dewan komisaris atau dewan direksi jika saham yang dimiliki kurang dari $25 \%$.

Definisi perusahaan keluarga menurut Andreas (2008) tentang kepemilikan 25\% saham keluarga sesuai dengan Keputusan Direksi PT Bursa Efek Jakarta Nomor: Kep-305/BEJ/072004, tentang saham pengendali. Menurut SK tersebut dalam peraturan nomor I-A tentang pencatatan saham dan efek bersifat ekuitas selain saham yang diterbitkan oleh perusahaan tercatat pada point I.15 menyebutkan bahwa pemegang saham pengendali adalah pemegang saham yang memiliki $25 \%$ atau lebih saham perusahaan, atau pemegang saham yang memiliki kemampuan dengan cara apapun mempegaruhi pengelolaan dan/ atau kebijaksanaan perusahaan meskipun jumlah saham yang dimiliki kurang dari $25 \%$.

Perusahaan keluarga memiliki keuntungan dan kekurangan menurut Ward (2004) dalam Susanto et al., (2007:12). Kelebihan dari perusahaan keluarga, antara lain, (1) kesempatan 
bekerja sama, (2) saling percaya memperteguh keluarga dan bisnis, (3) kesempatan untuk menciptakan kekayaan, (4) sebagai cara untuk menurunkan nilai-nilai kepada anak-anak, (5) respek di masyarakat, dan (6) pengaruh yang lebih besar sebagai individu. Sedangkan kekurangan dari perusahaan keluarga, antara lain, potensi munculnya konflik antar keluarga, (2) munculnya kekecewaan ketika tujuan pribadi tidak tercapai, (3) terlalu banyak masalah financial, (3) hilangnya privasi yang disebabkan oleh publisitas, dan (4) rentan terhadap kritik dari luar keluarga.

\subsection{Penelitian Terdahulu}

Untuk masalah keagenan, hasil penelitian Catherine dan septiani (2017) menunjukkan bahwa birokrasi yang rendah diperusahaan keluarga membuat masalah keagenan menjadi lebih sederhana sehingga biaya keagean menjadi lebih rendah dan profitabilitas menjadi tinggi. Tujuan untuk mewariskan perusahaan pada generasi berikutnya membuat dilakukannya upayaupaya untuk mempertahankan perusahaan. Hasil yang berbeda ditunjukkan oleh penelitian Layyinaturrobaniyah dkk (2014), yaitu keberadaan keluarga tidak bisa membuat biaya keagenan menjadi turun. Ketidak mampuan keluarga dalam menurunkan biaya keagenan membuat utilisasi aset juga tidak meningkat.

Hasil penelitian Wijaya (2014) berupa studi kasus pada suatu perusahaan dikeluarga menunjukkan bahwa prinsip GCG perusahaan tidak semuanya bisa diterapkan. Meskipun transparansi sudah bisa diterapkan, akan tetapi akuntabilitas masih belum bisa diterapkan secara maksimal. Kepercayaan yang tinggi terhadap keluarga yang bekerja di perusahaan menimbulkan tumpang tindihnya fungsi sehingga akuntabilitas masih kurang penerapannya. Persepsi yang berbeda antara karyawan sekaligus keluarga dengan karyawan yang bukan keluarga menimbulkan konflik yang membuat beberapa standar operasional perusahaan kurang dipatuhi dengan baik.

Hasil penelitian Lestari dan Hariindahyani (2017) menunjukkan bahwa keberadaan unsur GCG perusahaan seperti dewan komisaris hanya sebatas formalitas saja sehingga keberadaannya tidak berfungsi secara maksimal. Pemegang saham mayoritas (keluarga) memiliki informasi lebih besar dibanding dewan komisaris.

Hasil penelitian Catherine dan Septiani (2017) juga menghasilkan sebuah kesimpulan investor dapat saja tidak percaya terhadap kompetensi pemimpin perusahaan, karena adanya unsur kekerabatan dalam pemilihan pimpinan perusahaan. Hasil penelitian Muawanah (2014) melengkapi hasil penelitian Catherine dan Septiani (2017), yaitu keberadaan regulasi pemerintah membuat dominasi keluarga dalam perusahaan sedikit terbatas meskipun nepotisme masih tetap berlaku.

Hasil penelitian Sanjaya (2014) menunjukkan bahwa adanya nepotisme dalam pemilihan pimpinan dan pejabat perusahaan tidak didasarkan kompetensi yang harus dipenuhi. Hal ini berakibat kemampuan perusahaan dalam mencapai kinerja yang bagus tidak maksimal.

Penelitian dewantoro (2011) berangkat dari mitos tentang perusahaan keluarga yaitu bahwa perusahaan keluarga tidak professional, tidak adanya pemisahan keuangan antara keuangan perusahaan dan keluarga, tidak dapat menerapkan system dan prosedur yang sehat, nepotisme tinggi, kinerja tidak penting, SDM tidak penting, dan berakhirnya perusahaan keluarga di generasi ke dua. Mitos yang menjadi latar belakang penelitian Dewantoro (2011) tidak dibuktikan dari hasil penelitiannya. Kinerja dan sistem pengendalian manajemen di perusahaan keluarga menunjukkan hasil yang baik. 


\subsection{Pengembangan Hipotesis}

1. Terdapat perbedaan biaya keagenan perusahaan keluarga dan perusahaan non keluarga

Teori keagenan menunjukkan bahwa terdapat perbedaan kepentingan antara pihak agen dan prinsipal Mecling (1976). Adanya informasi asymetri, yaitu dimana agen memiliki lebih banyak informasi dibanding prinsipal akan menimbulkan konflik keagenan. Konflik keagenan harus dinetralisasi dengan upaya monitoring dan kompensasi yang berarti membutuhkan biaya, yang disebut biaya keagenan.

Pada perusahaan keluarga, dimana pihak keluarga memiliki saham dominan atau principal juga sebagai agen, maka konflik kepentingan antara principal dan agen dapat di tiadakan akan tetapi berpeluang menimbulkan konflik kepentingan internal manajemen perusahaan antara manajemen yang menjadi bagian keluarga dan manajemen bukan keluarga.

Dari uraian pengembangan hipotesis yang dibangun, maka hipotesis yang diajukan adalah sebagai berikut:

H1: Terdapat perbedaan yang signifikan pada biaya keagenan antara perusahaan keluarga dan perusahaan non keluarga

\section{Terdapat perbedaan penerapan GCG antara perusahaan keluarga dan non keluarga}

Berangkat dari teori keagenan, yang menyatakan bahwa terdapat perbedaan kepentingan antara agen dan prinsipal yang dapat memicu timbulnya konflik keagenan. GCG perusahaan yang baik (Good Corporate Governance) merupakan salah satu alat yang bisa digunakan untuk menyelaraskan kepentingan antara agen dan prinsipal. GCG perusahaan yang baik akan memastikan bahwa agen melaksanakan tanggungjawabnya sesuai dengan kepentingan prinsipal.

Pada perusahaan keluarga, dimana prinsipal dapat berposisi sebagai agen, maka informasi asimetri dimungkinkan tidak terjadi. Prinsipal yang memiliki informasi yang sama dengan agen akan mengurangi munculnya konflik keagenan, sehingga kebutuhan monitoring akan berkurang. GCG perusahaan (Good Corporate Governance) yang menjadi alat untuk menyelaraskan kepentingan prinsipal dan agen, kemungkinan hanya sebatas formalitas saja untuk memenuhi kepentingan regulasi.

Kepemilikan keluarga dalam perusahaan akan membuat penerapan GCG perusahaan keluarga dan non keluarga akan berbeda. Dengan demikian hipotesis yang diajukan adalah sebagai berikut:

H2: Terdapat perbedaan penerapan GCG antara perusahaan keluarga dan non keluarga

\section{Terdapat Perbedaan Kinerja Antara Perusahaan Keluarga Dan Perusahaan Non Keluarga.}

Penerapan prinsip keagenan yang berbeda dalam perusahaan keluarga, meungkinkan timbulnya sinergi antara agen dan prinsipal. Sinergi berupa birokrasi yang sederhana dan kesamaan tujuan, akan mendorong agen mengambil kebijakan untuk mempertahankan keberlangsung hidup perusahaan. Pada perusahaan non keluarga, dimana prinsip keagenan diterapkan maka motif kompensasi manajemen dapat memicu agen untuk mengambil kebijakan yang lebih mengutamakan kinerja jangka pendek daripada jangka panjang. Dari penjelasan ini maka hipotesis yang diajukan adalah:

H3: terdapat perbedaan kinerja antara perusahaan keluarga dan perusahaan non keluarga 


\section{Metode Penelitian}

Penelitian ini menggunakan metode kuantitatif, dengan tingkat eksplanasi komparatif yaitu membandingkan nilai satu atau lebih variabel pada sampel. Tujuan yang ingin dicapai dari penelitian ini adalah untuk membuktikan apakah terdapat perbedaan antara biaya keagenan, GCG perusahaan, dan kinerja jangka panjang, antara perusahaan keluarga dan non keluarga. Untuk memenuhi tujuan tersebut, maka metode analisa yang digunakan adalah statistik komparatif.

Populasi dalam penelitian ini adalah perusahaan yang terdaftar secara berturut turut dalam indeks kompas 100 dalam periode 2017 sampai dengan 2019. Metode pemilihan sampel yang digunakan adalah metode sensus yaitu semua anggota populasi memiliki peluang menjadi sampel. Dari 100 perusahaan yang terdaftar dalam indeks, yang masuk dalam daftar selama tiga tahun berturut turut adalah sebanyak 71 perusahaan. Selanjutnya sampel tersebut di pisahkan menjadi sampel perusahaan keluarga dan non keluarga.

Pengidentifikasian perusahaan keluarga dan non keluarga dilakukan dengan tiga cara. Pertama, mengidentifikasi jumlah kepemilikan saham yang lebih dari $25 \%$ dikuasai oleh satu orang. Sebagaimana yang dikatakan oleh Andreas (2008), perusahaan keluarga dikelompokkan dalam dua kriteria yaitu a) pendiri atau anggota keluarga memiliki saham sebesar $25 \%$ atau lebih; dan b) terdapat anggota keluarga yang menduduki kursi dewan komisaris atau dewan direksi jika saham yang dimiliki kurang dari $25 \%$.

Cara berikutnya dalam mengidentifikasi perusahaan keluarga melalui penelusuran lebih mendalam atas kepemilikan institusional dalam perusahaan, seperti melalui melalui sejarah pendirian perusahaan. Hasil pengidentifikasian menunjukkan bahwa terdapat 28 perusahaan yang teridentifikasi sebagai perusahaan keluarga dan 43 bukan perusahaan keluarga

Variabel yang digunakan dalam penelitian ini adalah biaya keagenan, GCG, dan kinerja perusahaan. biaya keagenan diukur dengan menggunakan literatur akuntansi yaitu expense ratio, sebagaimana yang digunakan oleh Layyinaturrobbaniyah (2014). Expense Ratio adalah perbandingan antara beban operasi dan penjualan perusahaan. Variabel GCG perusahaan dilihat dari daftar perusahaan yang yang masuk Top 50 Biggest Market Cap and Mid Cap of Public Listed Companies in Indonesia Institute for corporate Directoryshiya (IICD) selama periode pengamatan. Nilai 1 untuk perusahaan yang masuk top 50 biggest market and mid. Nilai 2 untuk yang tidak masuk kategori biggest market Cap and Mid Cap. Variabel kinerja perusahaan yang digunakan adalah kinerja profitabilitas sebagaimana yang digunakan oleh Ariani dan Fitdiarini (2014) yaitu Return On Aset.

Data yang digunakan dalam penelitian ini adalah data sekunder dengan mendokumentasikan nilai biaya operasional, penjualan, laba bersih, total aset, dan GCG. Tehnik analisa data yang digunakan dalam penelitian ini adalah uji beda dua sampel independen.

\section{Hasil dan Pembahasan}

Hasil pengolahan data yang pertama disajikan adalah statistik deskriptif data yang disajikan menjadi dua kelompok, yaitu kelompok perusahaan keluarga dan kelompok perusahaan non keluarga. Selanjutnya diikuti dengan pembahasan dari hasil pengujian hipotesis yang dilakukan. Adapun tabel statistik deskriptif dapat dilihat pada tabel 1. 
Tabel 1. Statistik Deskriptif

\begin{tabular}{lrrrrrr}
\hline & Agenkelg & GCGkelg & ROAkelg & Agennonkelg & GCGnonkelg & ROAnonkelg \\
\hline Mean & 0.3317 & 1.7381 & 0.0674 & 0.4681 & 1.4109 & 0.0782 \\
Median & 0.221 & 2 & 0.0566 & 0.4278 & 1 & 0.0406 \\
Minimum & 0.04 & & 0 & 0.01 & 0 \\
Maximum & 0.95 & & 0.35 & 0.97 & 0.52 \\
\hline
\end{tabular}

Sumber: Data Diolah, 2020

Data statistik menunjukkan rata-rata biaya keagenan perusahaan keluarga lebih kecil daripada perusahaan non keluarga. Begitu juga dengan kinerja ROA juga menunjukkan hal yang sama. Hasil yang berbeda yang ditunjukkan untuk GCG dimana perusahaan keluarga lebih tinggi dibanding perusahaan non keluarga.

Hasil pengolahan data berikutnya adalah hasil dari pengujian hipotesis. Pengujian hipotesis dalam penelitian ini mempertimbangkan jenis data yang digunakan. Data yang digunakan untuk uji hipotesis 1 dan 3 adalah data nominal dan pengujian menggunakan Mann Whitney $U$. Keputusan diterima atau ditolaknya hipotesis didasarkan atas nilai Asymptotic Sig (2-sided test). Hipotesis diterima jika nilai signifikansi lebih kecil dari 0.05 .

Tabel 2. Hasil Pengujian Hipotesis

\begin{tabular}{|l|c|c|c|}
\hline \multicolumn{3}{|c|}{ Hasil Pengujian Hipotesis } \\
\hline \multicolumn{1}{|c|}{} & $\begin{array}{c}\text { Hipotesis 1: } \\
\text { Biaya } \\
\text { Keagenan }\end{array}$ & $\begin{array}{c}\text { Hipotesis 2: } \\
\text { GCG }\end{array}$ & $\begin{array}{c}\text { Hipotesis 3 } \\
\text { ROA }\end{array}$ \\
\hline Total N & 213 & 213 & 213 \\
\hline $\begin{array}{l}\text { Independent-Samples Mann-Whitney U: } \\
\text { Asymptotic Sig.(2-sided test) }\end{array}$ & .009 & & .468 \\
\hline $\begin{array}{l}\text { Pearson Chi-Square: } \\
\text { Asymptotic Significance (2-sided) }\end{array}$ & & .000 & \\
\hline
\end{tabular}

\section{Sumber: Data Diolah, 2020}

Pengujian hipotesis 2 didasarkan nilai signifikansi pearson Chi-Square. Hipotesis diterima jika nilai signifikansi lebih kecil dari 0.05 . Hasil pengujian hipotesis 2 ini menunjukkan nilai signifikansi Pearson Chi-Square GCG sebesar 0.000 dan ini lebih kecil dari 0.05 , yang berarti hipotesis diterima. Diterimanya hipotesis 2 membuktikan bahwa terdapat perbedaan GCG di perusahaan keluarga dan non keluarga.

Hasil pengujian hipotesis 3 menunjukkan hasil yang berbeda dengan hipotesis 1 . Nilai signifikansi yang dihasilkan sebesar 0.468 dan lebih besar dari 0.05 , yang berarti hipotesis di tolak. Ditolaknya hipotesis 3 ini memberikan gambaran bahwa tidak terdapat perbedaan ROA pada perusahaan keluarga dan non keluarga.

Hasil pengujian menunjukkan bahwa hipotesis 1 diterima yang berarti terdapat perbedaan biaya keagenan antara perusahaan keluarga dan non keluarga. Biaya keagenan dalam bentuk rasio biaya operasional atas penjualan membuktikan bahwa biaya operasional diperusahaan keluarga tidak dimanfaatkan untuk kepentingan manajemen semata. Keberadaan keluarga dalam kepemilikan saham dan manajemen perusahaan menyelaraskan tujuan antara principal dan agen sehingga konflik keagenan dapat dihindari dan berarti biaya keagenan dapat dikurangi.. 
Hasil penelitian ini sejalan dengan penelitian Catherine dan Septiani (2017) yang mengatakan bahwa birokrasi yang rendah di peruahaan keluarga membuat masalah keagenan menjadi lebih sederhana sehingga biaya keagenan menjadi lebih rendah. Hasil penelitian ini tidak sejalan dengan penelitian Layyinaturrobaniyah dkk (2014), yaitu keberadaan keluarga tidak bisa membuat biaya keagenan menjadi turun.

Hasil pengujian hipotesis 2 diterima yang berarti bahwa terdapat perbedaan GCG pada perusahaan keluarga dan non keluarga. Terbuktinya hipotesis ini menunjukkan bahwa dengan keberadaan kepemilikan saham oleh keluarga dan dalam manajemen perusahaan dapat menyelaraskan tujuan, sehingga monitoring tindakan manajemen bisa lebih kecil. Prinsipal dan sekaligus sebagai agen membuat kebutuhan pengawasan tindakan agen sudah tidak lagi jadi maalah.

Hasil pengujian hipotesis 2 ini sejalan dengan penelitian Wijaya (2014) dalam hal akuntabilitas, yaitu bahwa keberadaan keluarga dalam manajemen perusahaan membuat tingginya kepercayaan, sehingga akuntabilitas masih kurang penerapannya. Hasil penelitian ini juga sejalan dengan penelitian Lestari dan Hariindahyani (2017) yang mengatakan bahwa keberadaan unsure GCG seperti dewan komisaris hanya sebatas formalitas saja sehingga fungsinya tidak maksimal.

Hasil pengujian hipotesis 3 ditolak yang berarti bahwa tidak terdapat perbedaan kinerja secara antara perusahaan keluarga dan perusahaan non keluarga. Ditolaknya hipotesis ini memberikan gambaran bahwa perusahaan keluarga maupun non keluarga sama-sama berupaya menunjukkan kinerja yang bagus karena yang memiliki kepentingan pada perusahaan tidak hanya pemegang saham utama tetapi juga stakeholder lainnya seperti pihak bank, pemerintah, dan masyarakat. Perusahaan keluarga maupun non keluarga sama-sama ingin terlihat baik agar kepercayaan stakeholder lainnya tetap terjaga dan ini akan menjaga kelangsungan hidup perusahaan.

Hasil penelitian ini sejalan dengan penelitian Dewantoro (2011) yang tidak bisa membuktikan mitos bahwa perusahaan keluarga berakhir di generasi kedua. Kesamaan hasil penelitian ini menunjukkan bahwa perusahaan keluarga juga ingin mempertahankan keberlangsungan hidup perusahaannya seperti perusahaan non keluarga. Ditolaknya hipotesis 3 ini tidak sejalan dengan hasil penelitian Sanjaya (2014), Catherine dan Septiani (2017), Muawanah (2014) yang mengatakan unsur nepotisme dalam pemilihan manajer membuat kemampuan mencapai kinerja tidak maksimal. Ditolaknya hipotesis 3 ini menunjukkan meskipun adanya unsur nepotisme dalam penunjukan manajer tetapi upaya pencapaian kinerja tetap maksimal.

\section{Simpulan}

Dari hasil pengujian hipotesis, simpulan dari penelitian ini adalah:

1. Terdapat perbedaan antara biaya keagenan pada perusahaan keluarga dan non keluarga. Kecilnya konflik kepentingan dalam perusahaan keluarga membuat biaya keagenan di perusahaan keluarga lebih kecil dibandingkan perusahaan non keluarga.

2. Terdapat perbedaan antara GCG pada perusahaan keluarga dan non keluarga. Kecilnya konflik keagenan membuat peran GCG di perusahaan keluarga jadi tidak begitu berperan dibandingkan di perusahaan non keluarga

3. Tidak terdapat perbedaan signifikan kinerja pada perusahaan keluarga dan non keluarga. Manajer yang sekaligus sebagai pemilik sama-sama berupaya mencapai kinerja yang bagus karena untuk memberikan jaminan kepercayaan kepada stakeholder lainnya. 


\section{Daftar Pustaka}

AMBS. (2020)., Generasi Baru Pengusaha Muda Indonesia Tak Lagi Andalkan Model Bisnis Keluarga. Diunduh secara online: https://youngster.id/headline., (22 Agustus 2020).

Ariani, Dewi. Fitdiarini, Noorlaily. 2014. Peran keluarga pendiri dalam menciptakan kinerja keuangan dan nilai pasar perusahaan pada perusahaan keluarga. Jurnal Manajemen Teori Dan Terapan. Volume 7 no 2. pISSN 1979-3650., EISSN 2548-2149

Aronoff, Craig \& Ward, John \& McClure, Stephen. (2011). Family Business Ownership: How to Be an Effective Shareholder.

Andres, Christian. 2008. Family Ownership, Financing Constraints and Investment Decisions. Working Paper. University of Bonn.

Ang, James. S. Cole., Rebel. A., and L.J. Wuh. 2000. Agency Cost and Ownership Structure. The Journal of Finance. Vol LV, No. 1. 81-106

Catherine, Rissa, Jessica., Septiani, Aditya. 2017. Pengaruh Family Control Terhadap Profitabilitas Dan Nilai Perusahaan Pada Industri Barang Konsumsi di Indonesia., Halaman 1-10, Diponegoro Journal Of Accounting., Volume 6, Nomor 3, Tahun 201., EISSN 2337-3806

Chrisman, J. J., Chua, J. H., and Litz, R. A., (2004), 'Comparing the agency costs of family and non-family firms: Conceptual issues and exploratory evidence', Entrepreneurship: Theory \& Practice, 28(4), 335-354.

Claessens, S., Djankov, S. dan Lang, L.H.P. (2000). The Separation of Ownership and Control in East Asian corporations, Journal of Financial Economics, 58, 81-112.

Dewantoro, Djoko. Majalah Ekonomi., halaman 294-310., Tahun XXI, No. 3 Desember 2011.

Donnelley, Robert G. The family business. Dalam Aronoff et. al.(2002). "Family.Business Sourcebook".Merietta : Family Enterprise Publishers

Forum for Corporate Governance in Indonesia. 2001. Corporate Governance: Tata Kelola Perusahaan. Edisi Ketiga. Jakarta: Prentice Hall.

IICD. Corporate Governance Award. Diunduh seara online: http://iicd.or.id/en/iicdevent/corporate-governance-award/. (22 Agustus 2020)

Jensen, M.C. and Meckling, William. H. 1976. Theory of the Firm: Managerial Beha-vior, Agency Cost and Qwnership Structure. Journal of Financial Economics. Volume. 3 (4). 305-360.

Layyinaturrobaniyah. sudarsono, rachmat. fitriyana, desi. 2014. agency cost pada perusahaan keluarga dan non keluarga. Jurnal Siasat Bisnis. Halaman 169-179 volume 18 no 2. PISSN: 0853-7666., EISSN 2528-7001.

Lestari, Indah, Meliana, Go., Hariindahyani, Senny. 2017. Pengaruh Perusahaan Keluarga Dan Peran Komisaris Independen Terhadap Praktik Manajemen Laba Di Indonesia. Jurnal Akuntansi dan Teknologi informasi (JATI). Volume 11. ISSN 2614-8749.

Muawanah, Umi., (2014)., Corporate Governance dan Kepemilikan Keluarga, Jurnal Akuntansi Multiparadigma. halaman 170-344 Volume 5 No 2., pISSN 2086-7603., eISSN 20895879.

PWC.(2019)., Bisnis Keluarga Harus Percaya Pada Pemimpin Generasi Penerus., Diunduh secara online: https://www.pwc.com/id/en/media-centre/press-release/2019/indonesian. (27 desember 2020)

Sanjaya, I Putu Sugiartha (2014), "keluarga sebagai pemilik ultimat dan kinerja perusahaan". Simposium Nasional Akuntansi 17.

Susanto, A.B., Himawan Wijanarko, Patricia Susanto, dan Suwahjuhadi Mertosono. 2007. The Jakarta Consulting Group on Family Business. Jakarta: The Jakarta Consulting Group 


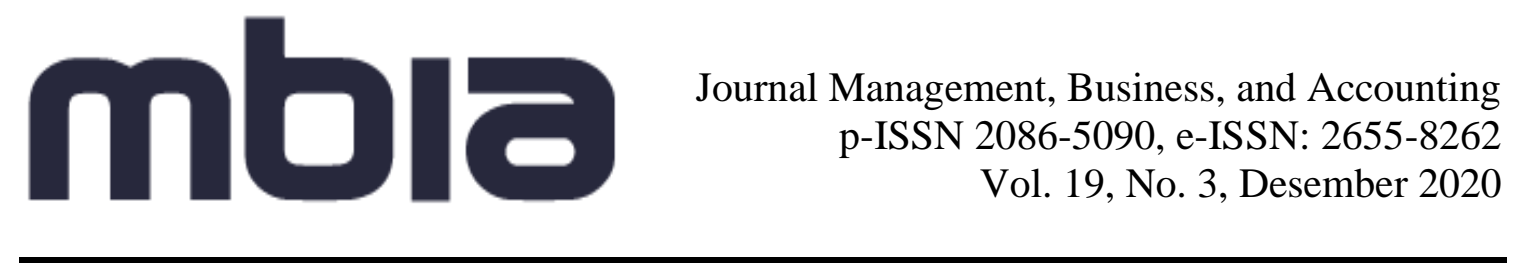

Villalonga, B. and Amit, R. (2006), "How do family ownership control and management affect firm value?" Journal of Financial Economics,. Volume 80, pp. 385-417

\section{Copyright Disclaimer}

Copyright for this article is retained by the author(s), with first publication rights granted to the journal. 